\title{
Energy Efficient Solar Charge Sensor Design Using Spartan-6 FPGA
}

\author{
Sujeet Pandey ${ }^{1}$, Gaurav Verma ${ }^{2}$, Bhagwan Das ${ }^{3}$, Tanesh \\ Kumar $^{4}$, Meenal Dhankar ${ }^{5}$ \\ ${ }^{1}$ Jain Univerrsity, Bangalore, India \\ ${ }^{2}$ Jaypee Institute of Information Technology, India \\ ${ }^{3} \mathrm{UTHM}$, Malaysia \\ ${ }^{4}$ Indus University, Karachi, Pakistan \\ ${ }^{5}$ Maharaja Surajmal Institute, New Delhi, India \\ welcomesujeet@gmail.com, gaurav.iitkg@gmail.com, engr.bhagwandas@ hotmail.com, \\ tanesh.nust@gmail.com, minal.dhankar@gmail.com
}

\begin{abstract}
Over charging of batteries as well as not charging discharged batteries in time spoils battery life. Human life is becoming very busy and many people do not care about how to do with batteries. Solar Charge Sensor Design is introduced to sense the voltage level of battery. It gives indication according to the voltage level to user. This will increase the life span of battery and make them work efficiently .Low Voltage Complementary metal oxide semiconductor i.e. LVCMOS25 standard on Spartan6 FPGA is used for making Solar Charge Sensor energy efficient and precise.
\end{abstract}

Keywords- Battery, Solar Charge Sensor, Field Programmable Gate Array, Charging.

\section{INTRODUCTION}

This paper is about making a sensor efficient which makes batteries to work $\mathrm{n}$ efficient manner by increasing their performance. Solar Charger Sensor senses the voltage level of the battery and tells user that it is time to charge battery now or battery is sufficiently charged as per the requirement. The charging of battery will automatically stop when sensor will indicate that battery is charged sufficiently. So there is no fear of overcharging. To make Solar Charge Sensor to use low power the research is done for Low Voltage Complementary Metal Oxide LVCMOS25 standard based on Spatan6 Field Programmable array using capacitance scaling. The value of different parameters and total power used by solar charge sensor is noted down over a range of output Load. The data is collected for $1 \mathrm{GHz}, 10 \mathrm{GHz}$ and $100 \mathrm{GHz}$. To what extent power consumption is reduced is noted down and calculated as percentage reduction. The reductions in all the factors are analyzed and then plotted for easy understanding. Solar Charge Sensor has many Properties. It not only checks for voltage level and indicates the need but also helps to achieve better performance in many ways. Some of the features of Sensor that makes the battery life long are shown in figure1.

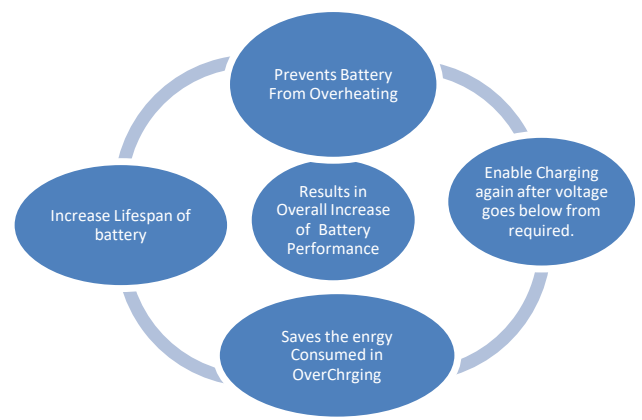

Figure 1: Factors Result in Better Performance 


\section{RELATED WORK}

The research needs to be done in this field. Very less work has already done in this field. A paper i.e. LVCMOS based energy efficient solar charge sensor design on FPGA [1] has done some work . This paper is similar to our paper as the approaches are similar to attain the low power solar charge sensor. The software used is also Xilinx for the interpretation of Data .The technique used is however different. We have used Capacitance Scaling for LVCMOS25 at three different frequencies. Where as in this paper frequency scaling is done based on LVCMOS15, LVCMOS18, LVCMOS25 and LVCMOS33. The frequency considered is $900 \mathrm{MHz}, 5 \mathrm{GHz}$ and $60 \mathrm{GHz}$. Field Programmable Array used in our paper is Spartan-6 instead of 28nm Artix-7 FPGA. Except this there is some work which is done for efficient charging of capacitors [2] for extended lifespan. For making systems energy efficient the work is done for ALU on 40nm FPGA [3] , signal process using FPGA[4] etc. But the idea of making sensors for indication of battery charging is still not that touched and work should be necessarily done for this.

\section{RESEARCH TECHNIQUE}

Xilinx Integrated Synthesis Environment Design Suite 12.1 used analyzing the design which is based on Spartan-6 FPGA for LVCMOS25 standard. Xilinx is tool for analyzing designs for various factors. The Capacitance is scaled from $10 \mathrm{pF}$ to $100 \mathrm{pF}$ for $1 \mathrm{GHz}, 10 \mathrm{GHz}$ and $100 \mathrm{GHz}$. Overall downturn in power consumption for the sensor is studied. Top Level RTL schematic for Solar Charge Sensor obtained using Xilinx is shown in Fig. 2.

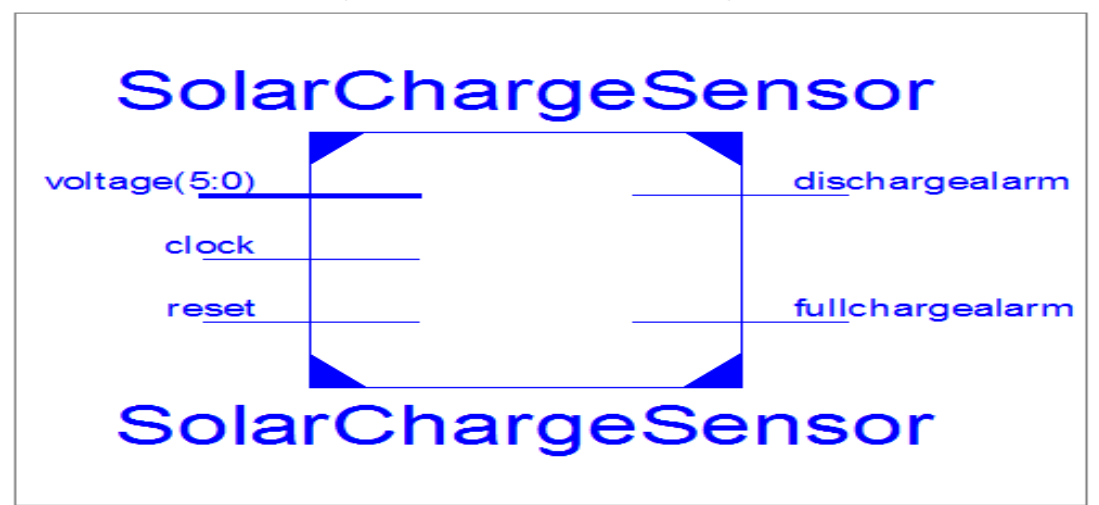

Figure 2: RTL Schematic of Solar Charger Sensor

\section{DATA ANALYSIS AND INTERPRETATION}

\section{A. Readings at Frequency $1 \mathrm{GHz}$}

Values for Junction Temperature, Ambient Temperature, IOs and Total Power are shown in Table1.

Table 1: Readings for Temperature, I/O and Total Power at $1 \mathrm{GHz}$ for $10 \mathrm{pF}-50 \mathrm{pF}$ Capacitance

\begin{tabular}{|l|l|l|l|l|l|}
\hline Output Load $(\mathrm{pF})$ & 10 & 20 & 30 & 40 & 50 \\
\hline $\begin{array}{l}\text { Junction } \\
\text { Temperature }\left({ }^{\circ} \mathrm{C}\right)\end{array}$ & 26.3 & 26.3 & 26.4 & 26.5 & 26.5 \\
\hline $\begin{array}{l}\text { Ambient } \\
\text { Temperature }\left({ }^{\circ} \mathrm{C}\right)\end{array}$ & 83.7 & 83.7 & 83.6 & 83.5 & 83.5 \\
\hline IOs & 0.007 & 0.009 & 0.010 & 0.012 & 0.013 \\
\hline Total Power & 0.030 & 0.031 & 0.033 & 0.035 & 0.036 \\
\hline
\end{tabular}

Percentage downturn in Junction Temperature is $0 \%, 0.37 \%, 0.75 \%$ and $0.75 \%$ when we downturn output load from $50 \mathrm{pF}$ to $40 \mathrm{pF}, 30 \mathrm{pF}, 20 \mathrm{pF}$ and $10 \mathrm{pF}$ respectively. Percentage 
Gyancity Journal of Electronics and Computer Science,

Vol.1, No.1, pp.18-24, September 2016

ISSN: 2446-2918 DOI: 10.21058/gjecs.2016.11004

downturn in Ambient Temperature is $0 \%, 0.37 \%, 0.75 \%$ and $0.75 \%$ when we upturn output load from $10 \mathrm{pF}$ to $20 \mathrm{pF}, 30 \mathrm{pF}, 40 \mathrm{pF}$ and $50 \mathrm{pF}$ respectively. Percentage downturn in I/Os is $7.69 \%, 23.07 \%, 30.76 \%$ and $46.15 \%$ when we downturn output load from $50 \mathrm{pF}$ to $40 \mathrm{pF}, 30 \mathrm{pF}$, $20 \mathrm{pF}$ and $10 \mathrm{pF}$ respectively. Percentage downturn in Total Power is $2.7 \%, 8.33 \%, 13.88 \%$ and $16.66 \%$ when we downturn output load from $50 \mathrm{pF}$ to $40 \mathrm{pF}, 30 \mathrm{pF}, 20 \mathrm{pF}$ and $10 \mathrm{pF}$ respectively which is shown graphically in Fig. 3.

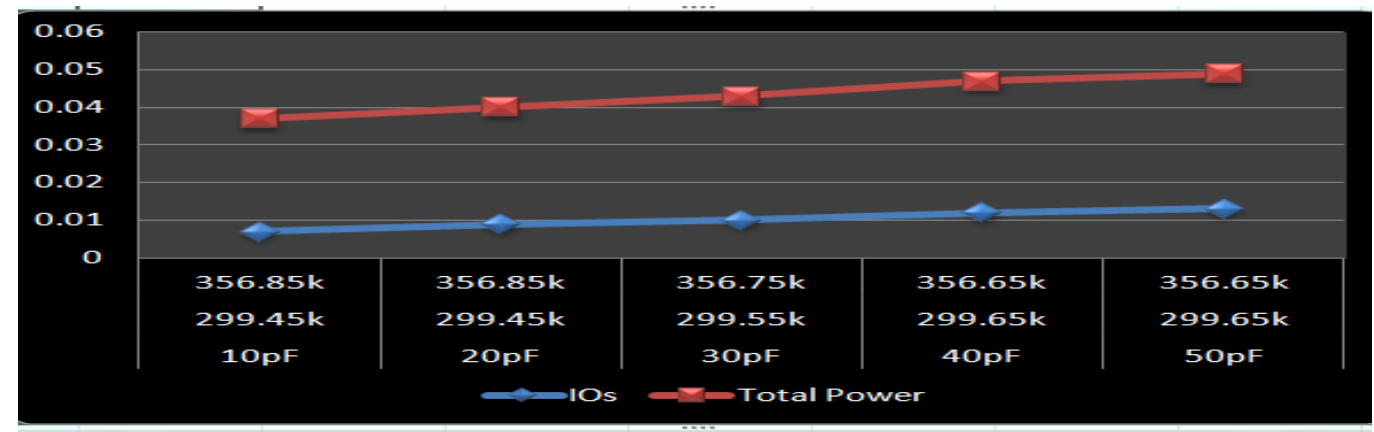

Figure3: Graphical Representation 0f Temperature, I/O and Total Power at 1GHz for 10pF-50pF Capacitance

Values for Junction Temperature, Ambient Temperature, IOs and Total Power are shown in Table2.

Table2: Readings for Temperature, $\mathrm{I} / \mathrm{O}$ and Total Power at $1 \mathrm{GHz}$ for $60 \mathrm{pF}-100 \mathrm{pF}$ Capacitance

\begin{tabular}{|l|l|l|l|l|l|}
\hline Output Load $(\mathrm{pF})$ & 60 & 70 & 80 & 90 & 100 \\
\hline $\begin{array}{l}\text { Junction } \\
\text { Temperature }\left({ }^{0} \mathrm{C}\right)\end{array}$ & 26.6 & 26.6 & 26.7 & 26.8 & 26.9 \\
\hline $\begin{array}{l}\text { Ambient } \\
\text { Temperature }\left({ }^{0} \mathrm{C}\right)\end{array}$ & 83.4 & 83.4 & 83.3 & 83.2 & 83.1 \\
\hline IOs & 0.015 & 0.015 & 0.018 & 0.020 & 0.021 \\
\hline Total Power & 0.038 & 0.038 & 0.041 & 0.043 & 0.044 \\
\hline
\end{tabular}

Percentage downturn in Junction Temperature is $0.37 \%, 0.74 \%, 1.11 \%$ and $1.11 \%$ when we downturn output load from $100 \mathrm{pF}$ to $90 \mathrm{pF}, 80 \mathrm{pF}, 70 \mathrm{pF}$ and $60 \mathrm{pF}$ respectively. Percentage downturn in Ambient Temperature is $0.11 \%, 0.11 \%, 0.23 \%$ and $0.35 \%$ when we upturn output load from $60 \mathrm{pF}$ to $70 \mathrm{pF}, 80 \mathrm{pF}, 90 \mathrm{pF}$ and $100 \mathrm{pF}$ respectively. Percentage downturn in I/Os is $4.76 \%, 14.28 \%, 28.57 \%$ and $28.57 \%$ when we downturn output load from $100 \mathrm{pF}$ to $90 \mathrm{pF}$, $80 \mathrm{pF}, 70 \mathrm{pF}$ and $60 \mathrm{pF}$ respectively. Percentage downturn in Total Power is $2.27 \%, 9.09 \%$, $13.63 \%$ and $13.63 \%$ when we downturn output load from $100 \mathrm{pF}$ to $90 \mathrm{pF}, 80 \mathrm{pF}, 70 \mathrm{pF}$ and $60 \mathrm{pF}$ respectively as shown in Fig. 4.

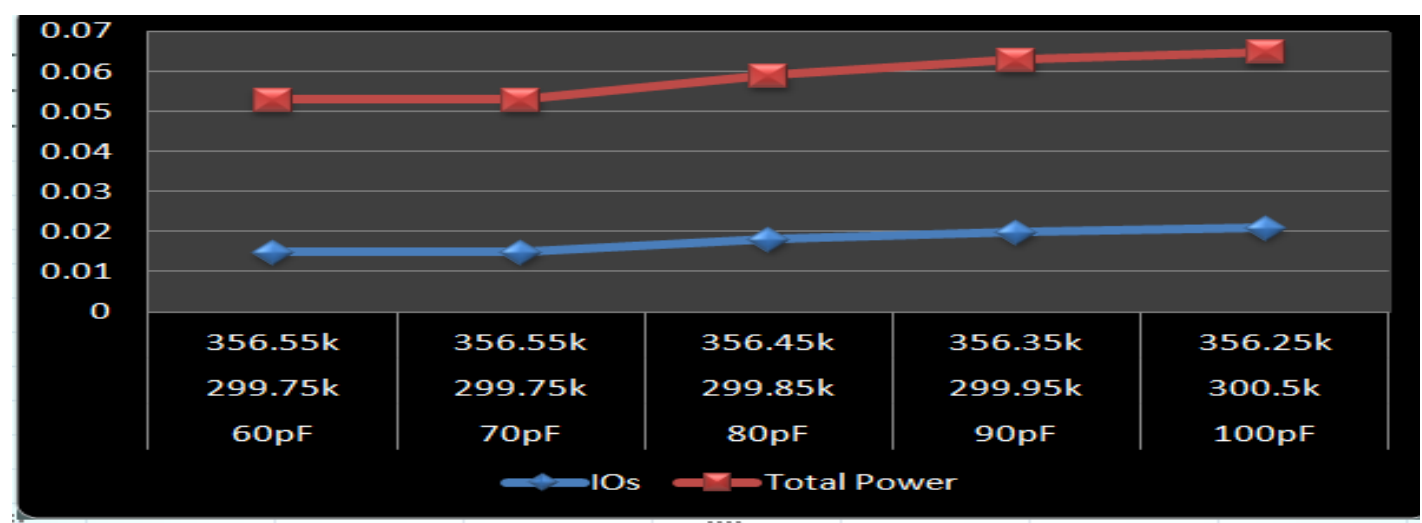

Figure4: Graphical Representation Of Temperature, I/O and Total Power at $1 \mathrm{GHz}$ for 60pF-100pF Capacitance 
Gyancity Journal of Electronics and Computer Science,

Vol.1, No.1, pp.18-24, September 2016

ISSN: 2446-2918 DOI: 10.21058/gjecs.2016.11004

\section{B. Readings at Frequency $10 \mathrm{GHz}$}

Values for Junction Temperature, Ambient Temperature, IOs and Total Power are shown in Table3.

Table 3: Readings for Temperature, I/O and Total Power at $10 \mathrm{GHz}$ for $10 \mathrm{pF}-50 \mathrm{pF}$ Capacitance

\begin{tabular}{|l|l|l|l|l|l|}
\hline Output Load $(\mathrm{pF})$ & 10 & 20 & 30 & 40 & 50 \\
\hline $\begin{array}{l}\text { Junction } \\
\text { Temperature }\left({ }^{0} \mathrm{C}\right)\end{array}$ & 32.4 & 33.1 & 33.8 & 34.5 & 35.2 \\
\hline $\begin{array}{l}\text { Ambient } \\
\text { Temperature }\left({ }^{0} \mathrm{C}\right)\end{array}$ & 77.6 & 76.9 & 76.2 & 75.5 & 74.8 \\
\hline IOs & 0.069 & 0.085 & 0.102 & 0.118 & 0.134 \\
\hline Total Power & 0.174 & 0.191 & 0.207 & 0.223 & 0.240 \\
\hline
\end{tabular}

Percentage downturn in Junction Temperature is $1.98 \%, 3.977 \%, 5.96 \%$ and $7.95 \%$ when we downturn output load from $50 \mathrm{pF}$ to $40 \mathrm{pF}, 30 \mathrm{pF}, 20 \mathrm{pF}$ and $10 \mathrm{pF}$ respectively. Percentage downturn in Ambient Temperature is $0.90 \%, 1.80 \%, 2.70 \%$ and $3.60 \%$ when we upturn output load from $10 \mathrm{pF}$ to $20 \mathrm{pF}, 30 \mathrm{pF}, 40 \mathrm{pF}$ and $50 \mathrm{pF}$ respectively. Percentage downturn in I/Os is $11.94 \%, 23.88 \%, 36.56 \%$ and $48.50 \%$ when we downturn output load from $50 \mathrm{pF}$ to $40 \mathrm{pF}$, $30 \mathrm{pF}, 20 \mathrm{pF}$ and $10 \mathrm{pF}$ respectively. Percentage downturn in Total Power is $7.08 \%, 13.75 \%$, $20.4 \%$ and $27.5 \%$ when we downturn output load from $50 \mathrm{pF}$ to $40 \mathrm{pF}, 30 \mathrm{pF}, 20 \mathrm{pF}$ and $10 \mathrm{pF}$ respectively as shown in Fig. 5.

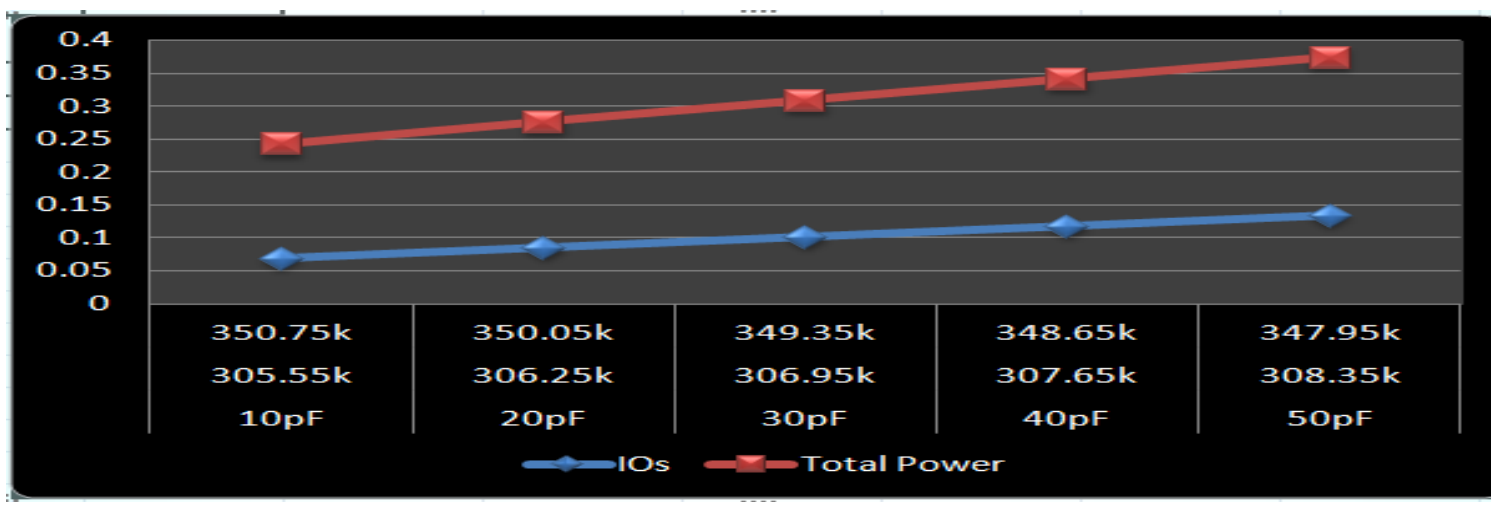

Figure5: Graphical Representation 0f Temperature, I/O and Total Power at 10GHz for 10pF-50pF Capacitance

Values for Junction Temperature, Ambient Temperature, IOs and Total Power are shown in Table4.

Table 4: Readings for Temperature, I/O and Total Power at 10GHz for 60pF-100pF Capacitance

\begin{tabular}{|l|l|l|l|l|l|}
\hline Output Load $(\mathrm{pF})$ & 60 & 70 & 80 & 90 & 100 \\
\hline $\begin{array}{l}\text { Junction } \\
\text { Temperature }\left({ }^{0} \mathrm{C}\right)\end{array}$ & 35.9 & 36.6 & 37.2 & 37.9 & 38.6 \\
\hline $\begin{array}{l}\text { Ambient } \\
\text { Temperature }\left({ }^{0} \mathrm{C}\right)\end{array}$ & 74.1 & 73.4 & 72.8 & 72.1 & 71.4 \\
\hline IOs & 0.150 & 0.166 & 0.182 & 0.198 & 0.214 \\
\hline Total Power & 0.256 & 0.272 & 0.289 & 0.305 & 0.321 \\
\hline
\end{tabular}

Percentage downturn in Junction Temperature is $1.81 \%, 3.626 \%, 5.18 \%$ and $6.99 \%$ when we downturn output load from $100 \mathrm{pF}$ to $90 \mathrm{pF}, 80 \mathrm{pF}, 70 \mathrm{pF}$ and $60 \mathrm{pF}$ respectively. Percentage downturn in Ambient Temperature is $0.94 \%, 1.75 \%, 2.69 \%$ and $3.64 \%$ when we upturn output load from $60 \mathrm{pF}$ to $70 \mathrm{pF}, 80 \mathrm{pF}, 90 \mathrm{pF}$ and $100 \mathrm{pF}$ respectively. Percentage downturn in I/Os is $7.47 \%, 14.95 \%, 22.42 \%$ and $29.90 \%$ when we downturn output load from $100 \mathrm{pF}$ to $90 \mathrm{pF}$, 
Gyancity Journal of Electronics and Computer Science,

Vol.1, No.1, pp.18-24, September 2016

ISSN: 2446-2918 DOI: 10.21058/gjecs.2016.11004

$80 \mathrm{pF}, 70 \mathrm{pF}$ and $60 \mathrm{pF}$ respectively. Percentage downturn in Total Power is $4.984 \%, 9.96 \%$, $15.26 \%$ and $20.24 \%$ when we downturn output load from $100 \mathrm{pF}$ to $90 \mathrm{pF}, 80 \mathrm{pF}, 70 \mathrm{pF}$ and $60 \mathrm{pF}$ respectively as shown in Fig. 6.

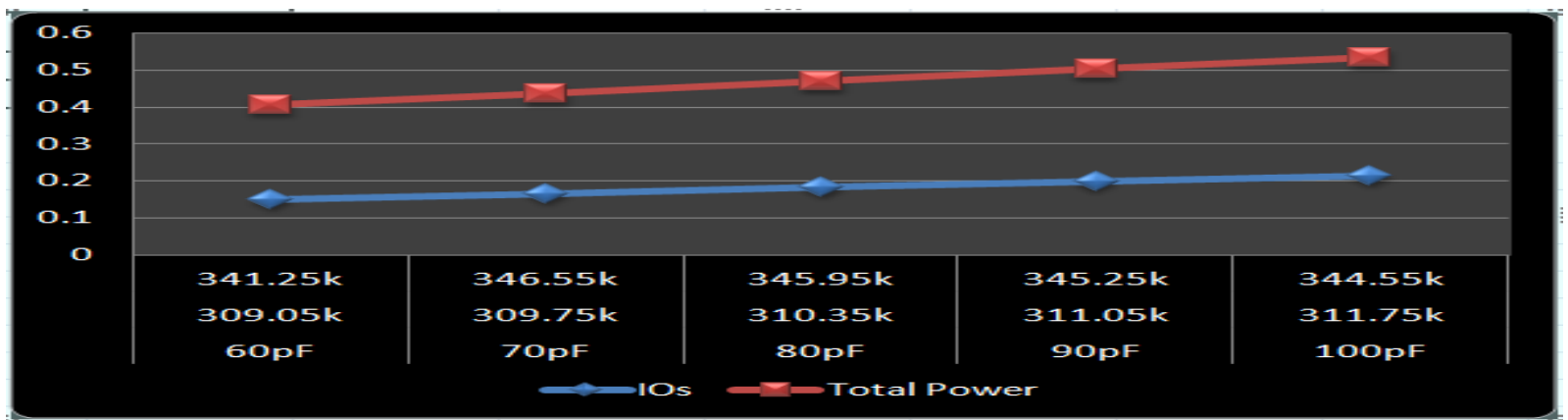

Figure 6: Graphical Representation of Temperature, I/O and Total Power at 10GHz for 60pF-100pF Capacitance

\section{Readings at Frequency $100 \mathrm{GHz}$}

Values for Junction Temperature, Ambient Temperature, IOs and Total Power are shown in Table5.

Table 5: Readings for Temperature, I/O and Total Power at $100 \mathrm{GHz}$ for $10 \mathrm{pF}-50 \mathrm{pF}$ Capacitance

\begin{tabular}{|l|l|l|l|l|l|}
\hline Output Load $(\mathrm{pF})$ & 10 & 20 & 30 & 40 & 50 \\
\hline $\begin{array}{l}\text { Junction } \\
\text { Temperature }\left({ }^{0} \mathrm{C}\right)\end{array}$ & 93.6 & 100.4 & 107.2 & 114.1 & 120.9 \\
\hline $\begin{array}{l}\text { Ambient } \\
\text { Temperature }\left({ }^{0} \mathrm{C}\right)\end{array}$ & 16.4 & 9.6 & 2.8 & -4.1 & -10.9 \\
\hline IOs & 0.693 & 0.854 & 1.015 & 1.177 & 1.338 \\
\hline Total Power & 1.617 & 1.778 & 1.939 & 2.101 & 2.262 \\
\hline
\end{tabular}

Percentage downturn in Junction Temperature is $5.62 \%, 11.33 \%, 16.95 \%$ and $22.58 \%$ when we downturn output load from $50 \mathrm{pF}$ to $40 \mathrm{pF}, 30 \mathrm{pF}, 20 \mathrm{pF}$ and $10 \mathrm{pF}$ respectively. Percentage downturn in Ambient Temperature is $41.46 \%, 82.92 \%, 125 \%$ and $166 \%$ when we upturn output load from $10 \mathrm{pF}$ to $20 \mathrm{pF}, 30 \mathrm{pF}, 40 \mathrm{pF}$ and $50 \mathrm{pF}$ respectively. Percentage downturn in $\mathrm{I} / \mathrm{Os}$ is $12.03 \%, 24.14 \%, 36.17 \%$ and $48.20 \%$ when we downturn output load from $50 \mathrm{pF}$ to $40 \mathrm{pF}$, $30 \mathrm{pF}, 20 \mathrm{pF}$ and $10 \mathrm{pF}$ respectively. Percentage downturn in Total Power is $7.11 \%, 14.27 \%$, $21.39 \%$ and $16.66 \%$ when we downturn output load from $50 \mathrm{pF}$ to $40 \mathrm{pF}, 30 \mathrm{pF}, 20 \mathrm{pF}$ and $10 \mathrm{pF}$ respectively as shown in Fig. 7.

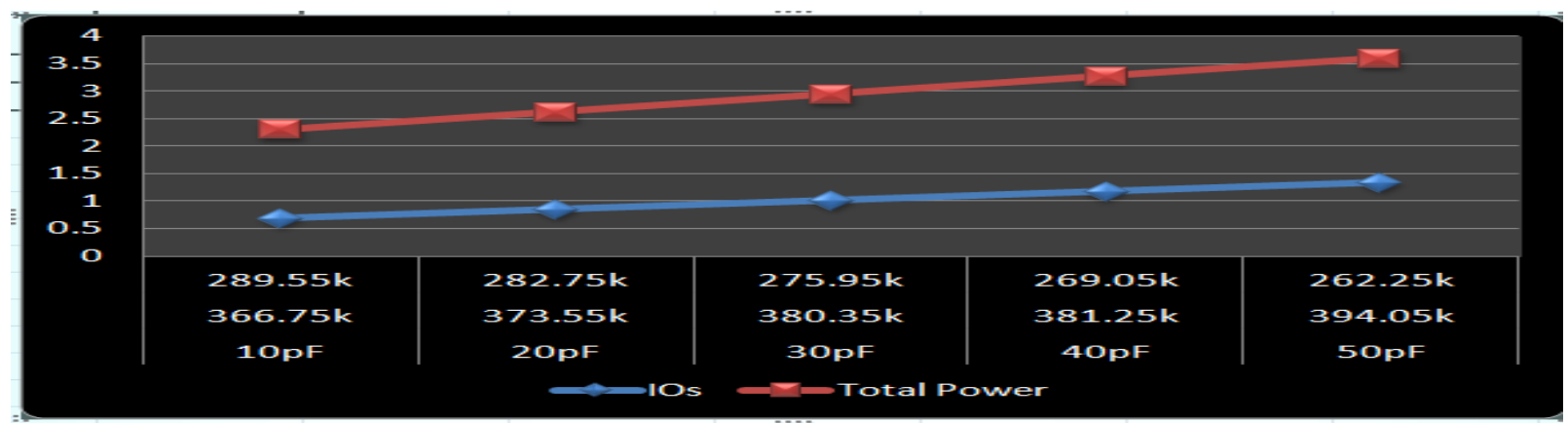

Figure 7: Graphical Representation of Temperature, I/O and Total Power at 100GHz for 10pF-50pF Capacitance

Values for Junction Temperature, Ambient Temperature, IOs and Total Power are shown in Table6. 
Gyancity Journal of Electronics and Computer Science,

Vol.1, No.1, pp.18-24, September 2016

ISSN: 2446-2918 DOI: 10.21058/gjecs.2016.11004

Table 6: Readings for Temperature, I/O and Total Power at $1 \mathrm{GHz}$ for $60 \mathrm{pF}-100 \mathrm{pF}$ Capacitance

\begin{tabular}{|l|l|l|l|l|l|}
\hline Output Load $(\mathrm{pF})$ & 60 & 70 & 80 & 90 & 100 \\
\hline $\begin{array}{l}\text { Junction } \\
\text { Temperature }\left({ }^{0} \mathrm{C}\right)\end{array}$ & 125 & 125 & 125 & 125 & 125 \\
\hline $\begin{array}{l}\text { Ambient } \\
\text { Temperature }\left({ }^{0} \mathrm{C}\right)\end{array}$ & -17.7 & -24.6 & -31.4 & -38.3 & -45.1 \\
\hline IOs & 1.499 & 1.660 & 1.822 & 1.983 & 2.144 \\
\hline Total Power & 2.423 & 2.584 & 2.746 & 2.907 & 3.068 \\
\hline
\end{tabular}

Junction Temperature remains constant when we downturn output load from $100 \mathrm{pF}$ to $90 \mathrm{pF}$, $80 \mathrm{pF}, 70 \mathrm{pF}$ and $60 \mathrm{pF}$ respectively. Percentage downturn in Ambient Temperature is $-38.98 \%$, $-77.40 \%,-116.9 \%$ and $-154.80 \%$ when we upturn output load from $60 \mathrm{pF}$ to $70 \mathrm{pF}, 80 \mathrm{pF}, 90 \mathrm{pF}$ and $100 \mathrm{pF}$ respectively. Percentage downturn in I/Os is $7.50 \%, 15.01 \%, 22.57 \%$ and $30.08 \%$ when we downturn output load from $100 \mathrm{pF}$ to $90 \mathrm{pF}, 80 \mathrm{pF}, 70 \mathrm{pF}$ and $60 \mathrm{pF}$ respectively. Percentage downturn in Total Power is $5.24 \%, 10.49 \%, 15.77 \%$ and $21.02 \%$ when we downturn output load from $100 \mathrm{pF}$ to $90 \mathrm{pF}, 80 \mathrm{pF}, 70 \mathrm{pF}$ and $60 \mathrm{pF}$ respectively as shown in Fig. 8 .

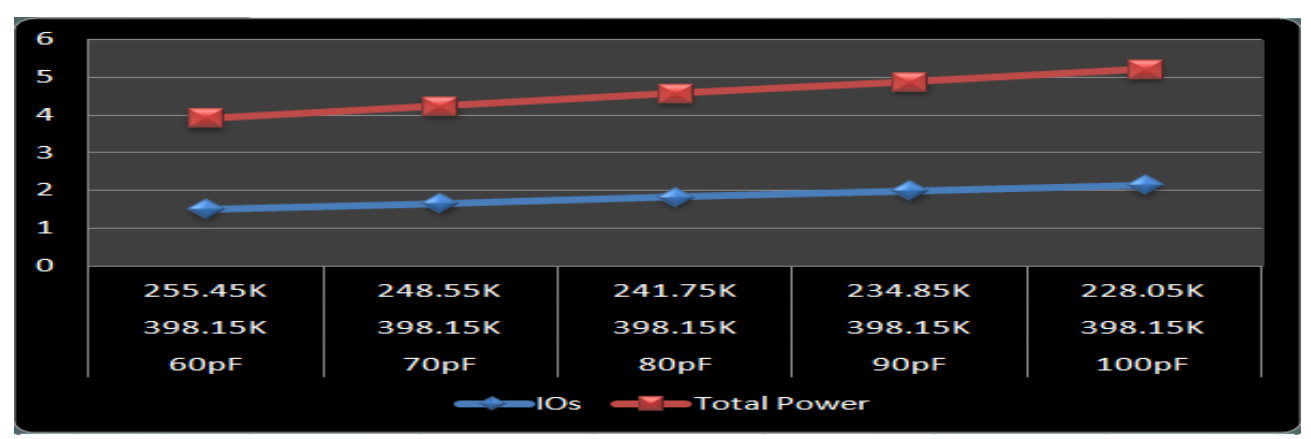

Figure 8: Graphical Representation of Temperature, I/O and Total Power at 100GHz for 60pF-100pF Capacitance

\section{Conclusion}

The data is obtained and plotted graphically. The power reductions are obtained at three frequencies. The maximum reduction in power is $16.66 \%, 20.24 \%$ and $27.2 \%$ for $1 \mathrm{GHz}$, $10 \mathrm{GHz}$ and $100 \mathrm{GHz}$ respectively. Also it is obtained that ambient temperature goes below 00C as shown in Table 7 and Table 8. The Junction temperature varies with output load at different frequencies but when frequency is $100 \mathrm{GHz}$ the Junction temperature attains a constant value i.e. $1250 \mathrm{C}$ even capacitance is changed from $60 \mathrm{pF}$ to $70 \mathrm{pF}, 80 \mathrm{pF}, 90 \mathrm{pF}$ and $100 \mathrm{pF}$. For easy understanding and plotting temperatures properly junction temperature and ambient temperature are converted to Kelvin scale.

\section{FUTURE SCOPE}

Solar Charger Sensor is a concept that can save the life of batteries and hence have a lot of scope for future. The study needs to be done in this concept and work should be done to make this sensor energy efficient. In future the work can be done for HSTL, SSTL, Mobile DDR [5] and many more. Different field programmable gate arrays can be considered for further research. Voltage Scaling can be done. The design can also be modified so that battery performance can be made as much better as possible. Many factors such as heating, current leakage etc can be reduced by further modifications in design for future. 
Gyancity Journal of Electronics and Computer Science,

Vol.1, No.1, pp.18-24, September 2016

ISSN: 2446-2918 DOI: 10.21058/gjecs.2016.11004

\section{REFERENCES}

[1] A.Singla, A. Kaur, and B.Pandey. "LVCMOS based energy efficient solar charge sensor design on FPGA." Power Electronics 6th India International Conference on. IEEE, 2014.

[2] Simjee, Farhan I., and Pai H. Chou. "Efficient charging of supercapacitors for extended lifetime of wireless sensor nodes." IEEE Transactions on power electronics 23.31526-1536.

[3] B. Pandey et al. "Energy efficient design and implementation of ALU on 40nm FPGA." Energy Efficient Technologies for Sustainability, International Conference on. IEEE, 2013.

[4] Choi, Seonil, et al. "Energy-efficient signal processing using FPGAs." Proceedings of the eleventh international symposium on Field programmable gate arrays. ACM, 2003.

[5] B. Pandey, V. Thind, S. K. Sandhu, T. Walia, and S. Sharma. "SSTL Based Power Efficient Implementation of DES Security Algorithm on 28nm FPGA." International Journal of Security and Its Application 9, no. 7, July 2015, Page: 267-274. 